\title{
ANALISIS TINDAK TUTUR EKSPRESIF DALAM BERITA DOKTER DETEKSI VIRUS CORONA MENINGGAL DI WUHAN PADA SALURAN YOUTUBE TRIBUNNEWS.COM
}

\author{
Ifatul Mu'awanah, Asep Purwo Yudi Utomo \\ Program Studi Sastra Indonesia \\ Jurusan Bahasa dan Sastra Indonesia \\ Fakultas Bahasa dan Seni \\ Universitas Negeri Semarang \\ ifatulmuawanah3@students.unnes.ac.id \\ aseppyu@mail.unnes.ac.id
}

\begin{abstract}
ABSTRAK
Bahasa merupakan alat komunikasi yang digunakan sebagai penyampai pesan dari penutur kepada mitra tutur. Dalam berkomunikasi akan menghasilkan tuturan dan kegiatan dalam melakukan tuturan disebut tindak tutur. Terdapat beberapa jenis tindak tutur salah satunya yaitu tindak tutur ekspresif. Secara umum, tujuan penelitian ini adalah memaparkan tindak tutur ekspresif yang terdapat pada salah satu berita yang memuat tentang virus corona. Virus corona masih diperbincangkan oleh khalayak ramai karena jumlah kematian yang disebabkan sangat tinggi dan kini telah menjangkiti hampir seluruh negara di belahan dunia. Objek penelitian ini yaitu sebuah berita berjudul Dokter yang Pertama Kali Deteksi Virus Corona Di Wuhan Meninggal dari sumber saluran youtube Tribunnews.com. Pendekatan dalam penelitian menggunakan pendekatan deskriptif kualitatif. Teknik yang digunakan untuk pengumpulan data adalah teknik catat. Adapun analisis data menggunakan langkahlangkah: mengidentifikasi, mengklasifikasi, menginterpretasi, melakukan pembahasan penelitian data, dan menyimpulkan. Hasil dari penelitian ini yaitu terdapat empat jenis tindak tutur ekspresif: mengkritik, memuji, meminta maaf, dan menyalahkan. Data terbanyak merujuk pada tindak tutur ekspresif mengkritik dan memuji, penutur mengkritik sebagian mitra tutur yang menjustifikasi seorang dokter yang memberikan informasi tentang virus corona dan penutur memuji dokter yang telah berhasil mendeteksi virus corona dan mengungkapkannya. Dari penelitian ini diharapkan pembaca memahami tindak tutur ekspresif dan lebih menghargai perjuangan seseorang yang bekerja keras serta tidak menjustifikasi orang tanpa adanya bukti.
\end{abstract}

Kata kunci: pragmatik, tindak tutur, tuturan ekspresif, dan virus corona

\begin{abstract}
Language is a communication tool used as a messenger from speakers to others. In communication, it will produce speech and activities in conducting speech acts are called speech acts. There are several types of speech acts, one of which is expressive speech acts. In general, the purpose of this study is to describe the expressive speech acts contained in one of the news that contains the corona virus. Corona virus is still being discussed by the public because the number of deaths caused is very high and has now infected almost all countries in the world. The object of this study is a news titled Doctor Who Detected Corona Virus First in Wuhan Died from YouTube channel Tribunnews.Com. The approach used in this research is a qualitative descriptive approach. The data collection technique used is the note taking technique. Analysis of the data in this study using steps: identifying, classifying, interpreting, conducting data research discussions, and concluding. The results of the discussion of this study are there are four types of expressive speech acts: criticizing, praising, apologizing, and blaming. Most data refers to criticizing and praising, speakers criticizing some speech partners
\end{abstract}


who justify doctors who provide information about the corona virus and speakers praising doctors who have succeeded in detecting the corona virus and expressing it. From this research the reader is expected to understand expressive speech acts and better appreciate the struggle of someone who works hard and does not justify people without evidence.

Keywords: pragmatics, speech acts, expressive speech, and corona virus.

\section{PENDAHULUAN}

Tuturan biasa digunakan dalam proses komunikasi. Dalam berkomunikasi terdapat minimal seorang penutur dan seorang mitra tutur. Penutur ialah orang yang menyampaikan gagasan, informasi, pikiran, dan maksud tertentu. Sedangkan mitra tutur yaitu orang yang menjadi sasaran penutur dalam memahami tuturannya. Tuturan dapat diekspresikan melalui media massa, baik tulisan ataupun lisan. Media massa yang dapat dimanfaatkan adalah media cetak dan media elektronik. Media cetak dapat berupa surat kabar, majalah, tabloid, dan media elektronik dapat berupa radio dan televisi.

Pada tuturan terdapat maksud sebenarnya yang hanya dapat diidentifikasi melalui situasi tutur yang mendukungnya. Leech (1983 : 13-15) berpendapat bahwa situasi tutur itu mencakupi lima komponen. Kelima komponen situasi tutur itu adalah penutur dan mitra tutur, konteks tuturan, tujuan tuturan, tindak tutur sebagai bentuk tindakan atau aktivitas, dan tuturan sebagai produk tindak verbal. Oleh Searle (1969) Tindak tutur yang tak terhitung jumlahnya dikelompokkan menjadi lima jenis sebagai berikut: representatif, direktif, ekspresif, komisitif, dan deklaratif. Tindak tutur ekspresif adalah tindak tutur yang dimaksudkan penuturnya agar ujarannya diartikan sebagai evaluasi tentang hal yang disebutkan dalam tuturan itu. Freaser (1978) menyebut tindak tutur ekspresif dengan istilah evaluatif. Tuturan-tuturan memuji, mengucapkan terima kasih, mengkritik, mengeluh, menyalahkan, mengucapkan selamat, menyanjung, termasuk ke dalam jenis tindak tutur ekspresif ini (Rustono 1999:41).

Penelitian ini difokuskan pada tindak tutur ekspresif yang terjadi akibat situasi tutur yang tengah ramai menjadi sorotan dan perbincangan dunia yaitu Covid-19 yang disebabkan oleh virus corona. Perlu diketahui sebelum virus corona menyebar luas hingga menjadi Pandemi, seorang Dokter dari salah satu Rumah Sakit di Wuhan, China bernama Dr. Li Wen Liang berhasil mendeteksi virus baru yang belum diketahui nama dan jenisnya namun sangat berbahaya. Virus ini menginfeksi saluran pernafasan dan mengakibatkan peradangan paru-paru hingga kematian. Namun peringatan yang dikatakan dokter Li sebelum meninggal itu ternyata tak dipedulikan oleh orang-orang dan bahkan dicibir. Berdasarkan berita yang didapatkan pada saluran youtube Tribunnews.com penutur berita mengungkapkan bahwa dokter Li Wen Liang sempat dicibir lantaran menyebarkan berita bohong tentang virus corona, namun karena berita itu benar warga setempat menyebutnya pahlawan. Sayangnya kini Dokter Li telah meninggal. 
Tidak disangka virus yang mengakibatkan peradangan paru-paru hingga kematian ini menggemparkan dunia dengan jumlah korban yang fantastis. Dilansir dari kompas.com Hingga Senin (13/4/2020), John Hopkins University mengumpulkan data yang telah dikonfirmasi bahwa jumlah kasus virus corona di seluruh dunia mencapai 1.846.680 kasus. Artinya, lebih dari 1,8 juta orang terinfeksi virus corona. Berdasarkan jumlah tersebut, dikonfirmasi meninggal dunia sejumlah 6,18 persen atau sebanyak 114.090 pasien. Adapun jumlah pasien yang dinyatakan sembuh mencapai 22,84 persen atau 421.722 orang. Hingga saat ini negara Amerika Serikat mencatatkan jumlah kasus terbanyak dengan lebih dari 500.000 kasus, kemudian disusul negara Spanyol, Italia, Perancis, dan Jerman. China sebagai negara yang pertama kali terdeteksi adanya virus corona tidak termasuk dalam lima besar negara dengan kasus terbanyak. Hal ini dikarenakan China telah mengambil langkah cepat setelah virus ini menginfeksi banyak orang sebelum kemudian dinyatakan sebagai Pandemi.

Dalam hal ini penulis melakukan penelitian terhadap tindak tutur ekspresif yang dilakukan oleh penutur berita dari saluran youtube Tribunnews.com tersebut karena tuturannya tersebut mengandung maksud yang ingin disampaikan kepada pendengar. Peneliti memilih topik penelitian tentang virus corona dari saluran youtube Tribunnews.com sebagai sumber penelitian karena tiga alasan. Alasan pertama yaitu mengacu tuturan yang digunakan oleh pembawa acara dalam berita yaitu tuturan ekpresif. Kedua, topik pembicaraan dalam berita ini adalah isu terhangat pada tahun 2020 dan banyak dibicarakan oleh semua lapisan masyarakat di seluruh dunia. Ketiga, Tribunnews merupakan media massa yang dikenal banyak masyarakat dengan menyebar berita-berita terhangat melalui berbagai situs. Dalam sebuah Jurnal Pengembangan Teknologi Informasi dan Ilmu Komputer analisis kualitas Tribunnews.com dinyatakan dengan sebuah pernyataan Variabel information quality berfokus pada kualitas informasi yang disajikan oleh pihak penyedia situs web Tribunnews. Secara keseluruhan, variabel ini berada pada kategori tinggi dengan tingkat kepuasan yang memuaskan.

\section{METODE}

Pendekatan yang digunakan dalam penelitian ini berupa pendekatan deskriptif kualitatif. Pendekatan deskriptif merupakan pendekatan dengan prosedur penelitian yang menghasilkan data deskripsi berupa kata-kata tertulis atau lisan dari orang-orang dan perilaku yang diamati (Moleong 2002:3). Pendekatan kualitatif adalah pendekatan dengan data yang diperoleh bukan berupa angkaangka, namun berupa kata-kata dan gambar. Sehingga hasil penelitian akan berupa kutipan-kutipan data untuk memberi gambaran penyajian (Moleong 2002:6). Sumber data dalam penelitian ini berupa tuturan yang disampaikan penutur berita dari tribunnews.com dalam menyampaikan berita dokter yang pertama kali deteksi virus corona di Wuhan meninggal. Pengumpulan data menggunakan teknik catat, yaitu teknik pengumpulan data yang dilakukan dengan pencatatan dari sumber data 
yang segera dilanjutkan dengan analisis. Data dalam penelitian ini dianalisis berdasarkan langkah-langkah sebagai berikut: (1) mengidentifikasi bentuk tindak tutur ekspresif, (2) mengklasifikasikan bentuk tindak tutur ekspresif, (3) menginterpretasi (memaknai) data yang telah diklasifikasikan berdasarkan bentuk tindak tutur ekspresif, (4) melakukan pembahasan penelitian data, (5) menyimpulkan.

\section{HASIL DAN PEMBAHASAN}

Hasil penelitian ini mencakup hal-hal yang sesuai dengan tujuan penelitian, yaitu memaparkan bentuk tindak tutur ekspresif yang terdapat dalam berita dokter yang pertama kali deteksi virus corona di Wuhan meninggal pada saluran youtube tribunnews.com. Ditemukan empat macam bentuk tindak tutur ekspresif, yaitu (1) mengkritik, kasih, (2) memuji, (3) menyalahkan, dan (4) memohon maaf.

\section{A. Tindak Tutur Ekspresif Mengkritik}

Penggunaan tindak tutur ekspresif mengkritik pada berita dokter yang pertama kali deteksi virus corona di Wuhan meninggal sebagai berikut.

\section{Data 1}

Konteks: Kritikan ditujukan kepada mitra tutur yang pernah menuduh dokter sebagai penyebar berita tidak benar.

Tuturan: "Dokter yang pertama kali mengumumkan tentang virus corona tersebut diketahui meninggal dunia pada Kamis, 6 Februari 2020. Dokter yang pernah dituduh sebagai penyebar berita tidak benar itu kini menjadi pahlawan karena pengetahuannya."

Data 1 terdapat pernyataan yang berupa tuturan ekspresif mengkritik "Dokter yang pernah dituduh sebagai penyebar berita tidak benar itu" disampaikan penyiar berita dengan maksud mengkritik mitra tutur yang pernah menuduh dokter sebagai penyebar berita tidak benar, padahal dokter itu berjasa mengumumkan berita penting yaitu virus corona untuk pertama kalinya bahkan ia kini disebut menjadi pahlawan karena pengetahuannya.

Data 2

Konteks: Kritikan ditujukan kepada mitra tutur yang pernah mencibir dokter sebagai penyebar berita bohong.

Tuturan: "dr. Li Wen Liang pernah sempat dicibir lantaran disebut menyebarkan berita bohong tentang virus corona, namun karena hal tersebut benar maka warga setempat menyebut dokter ini sebagai pahlawan."

Data 2 terdapat pernyataan yang berupa tuturan ekspresif mengkritik "dr. Li

Wen Liang pernah sempat dicibir lantaran disebut menyebarkan berita bohong tentang virus corona, namun karena hal tersebut benar..." disampaikan penyiar berita dengan maksud yang sama dengan data 1 yaitu mengkritik mitra tutur yang pernah mencibir dokter Li Wen Liang telah menyebarkan berita bohong tentang virus corona padahal dokter itu mengungkapkan yang sebenarnya. Dalam 
data 1 dan 2 terdapat persamaan dikarenakan letak penyampaian yang berbeda. Data 1 disampaikan penyiar berita pada pembukaan, sedangkan data 2 disampaikan dalam isi berita.

\section{Data 3}

Konteks: Kritikan yang ditujukan terhadap pihak berwenang di China yang menyatakan tidak ada yang terinfeksi, dan ditujukan pada petugas yang memintanya menandatangani surat tuduhan komentar palsu.

Tuturan: "Sesudah sakit Li Wen Liang mengunggah di media sosial wibo terkait pihak berwenang yang masih menyatakan tidak ada staf medis yang terinfeksi. Empat hari kemudian ia dikunjungi petugas medis dari Biro Keamanan Umun dan meminta dokter Li untuk menandatangani sepucuk surat. Surat tersebut berisi tuduhan bahwa Li Wen Liang membuat komentar palsu bersifat sangat menganggu ketertiban umum."

Data 3 terdapat pernyataan yang berupa tuturan ekspresif mengkritik "Sesudah sakit Li Wen Liang mengunggah di media sosial wibo terkait pihak berwenang yang masih menyatakan tidak ada staf medis yang terinfeksi..." disampaikan penyiar berita untuk mewakili kritikan yang dilakukan Li Wen Liang atas sikap pihak berwenang yang menyatakan tidak ada yang terinfeksi padahal ia sendiri tengah sakit karena terinfeksi virus tersebut, dan menyatakan betapa bahayanya virus tersebut. Dan ada lagi yaitu “...petugas medis dari Biro Keamanan Umun dan meminta dokter Li untuk menandatangani sepucuk surat. Surat tersebut berisi tuduhan bahwa Li Wen Liang membuat komentar palsu..." disampaikan penyiar berita dengan maksud mengkritik petugas medis dari Biro Keamanan Umum yang meminta dokter Li menandatangani surat berisi tuduhan bahwa ia membuat komentar palsu yang bersifat menganggu ketertiban umum, padahal dokter Li sendiri sedang berusaha menyelamatkan banyak nyawa dari virus corona dengan keadaan dirinya sendiri telah terpapar oleh virus itu.

\section{B. Tindak Tutur Ekspresif Memuji}

Penggunaan tindak tutur ekspresif memuji pada berita dokter yang pertama kali deteksi virus corona di Wuhan meninggal sebagai berikut.

Data 1

Konteks: Ungkapan yang memuji dokter yang berpengatahuan dan disebut pahlawan.

Tuturan: "Dokter yang pertama kali mengumumkan tentang virus corona tersebut diketahui meninggal dunia pada Kamis, 6 Februari 2020. Dokter yang pernah dituduh sebagai penyebar berita tidak benar itu kini menjadi pahlawan karena pengetahuannya."

Data 1 terdapat pernyataan berupa tuturan ekspresif memuji "Dokter yang pernah dituduh sebagai penyebar berita tidak benar itu kini menjadi pahlawan karena pengetahuannya." Dituturkan oleh penyiar berita dengan 
maksud memuji dokter yang disebut pahlawan karena pengetahuannya telah dapat mengumumkan berita besar yaitu tentang virus corona.

Data 2

Konteks: Ungkapan memuji dokter yang mampu mendeteksi virus

Tuturan: Dikutip dari Tribunstyle dokter tersebut mampu menjdeteksi virus corona sepuluh hari sebelum mewabah menjadi salah satu pengabdian Li Wen Lien sebagai dokter di Wuhan China.

Data 2 terdapat pernyataan berupa tuturan ekspresif memuji “...dokter tersebut mampu mendeteksi virus corona sepuluh hari sebelum mewabah..." dituturkan dengan maksud memuji dokter tersebut karena mampu mendeteksi virus corona sepuluh hari sebelum mewabah, seperti yang kita tahu bahwa virus corona menyerang dan menular dengan cepat apabila lambat dideteksi maka penyebarannya akan semakin luas. Ada pula "...menjadi salah satu pengabdian Li Wen Liang sebagai dokter di Wuhan China." Dituturkan dengan maksud memuji pengabdian dr Li Wen Liang yang sangat besar dan berdampak sangat baik bagi kesehatan China bahkan dunia, pengabdia yang tak terlupakan khususnya bagi warga Wuhan, China.

Data 3

Konteks: Ungkapan memuji dokter yang disebut pahlawan, dan sebagai satusatunya dokter yang mampu mendeteksi virus corona dan menyebarkan informasinya.

Tuturan: "dr. Li Wen Liang pernah sempat dicibir lantaran disebut menyebarkan berita bohong tentang virus corona, namun karena hal tersebut benar maka warga setempat menyebut dokter ini sebagai pahlawan. Diketahui dr. Li Wen Liang adalah satu-satunya dokter yang mampu mendeteksi gejala virus corona pada awal penyebaran. Li Wen Liang juga sempat memberitahukan penemuannya kepada rekan-rekan medis."

Data 3 terdapat pernyataan yang berisi beberapa tuturan ekspresif memuji (1) "warga setempat menyebut dokter ini sebagai pahlawan.” (2) “dr. Li Wen Liang adalah satu-satunya dokter yang mampu mendeteksi gejala virus corona pada awal penyebaran." (3) "Li Wen Liang juga sempat memberitahukan penemuannya kepada rekan-rekan medis." Ketiga tuturan tersebut dituturkan dengan maksud untuk memuji dokter Li Wen Lian atas prestasinya sebagai dokter yang menyebarkan infromasi terkait virus corona hingga disebut sebagai pahlawan oleh warga setempat, kemudian menjadi satu-satunya dokter yang mampu mendeteksi gejala virus corona pada awal penyebaran yang sangat bermanfaat hingga sekarang karena beberapa pasien corona dapat diketahui dari gejala yang ditimbulkan sehingga dapat segera di isolasi supaya tak menjangkit ke orang lain. Dan dokter Li sebelum meninggal juga telah memberitahukan penemuannya yang luar biasa tersebut kepada rekan-rekan medis yang lain supaya dapat menangani pasien dengan semestinya. 


\section{Tindak Tutur Ekspresif Meminta Maaf}

Penggunaan tindak tutur ekspresif meminta maaf pada berita dokter yang pertama kali deteksi virus corona di Wuhan meninggal sebagai berikut.

Data

Konteks: Ungkapan meminta maaf dari pemerintah kepada dr. Li Wen Liang Tuturan: "Pada akhir januari dokter Li menerbitkan salinan surat tersebut di media sosial wibo dan menjelaskan apa yang sebenarnya telah terjadi . karena hal tersebut akhirnya pemerintah meminta maaf namun sudah terlambat."

Pada data tersebut terdapat tuturan ekspresif meminta maaf “...karena hal tersebut akhirnya pemerintah meminta maaf..." dituturkan oleh penyiar berita dengan maksud mewakili ungkapan permintaan maaf pemerintah yang ditujukan kepada dokter Li atas sikap tidak baik terhadap dokter Li dengan memnintanya menandatangani surat tuduhan telah membuat komentar palsu, padahal komentar tersebut berisikan informasi yang besar dan penting.

\section{Tindak Tutur Ekspresif Menyalahkan}

Penggunaan tindak tutur ekspresif menyalahkan pada berita dokter yang pertama kali deteksi virus corona di Wuhan meninggal sebagai berikut.

Data

Konteks: Ungkapan menyalahkan penutur terhadap pemerintah atas sikapnya Tuturan: "Pada akhir januari dokter Li menerbitkan salinan surat tersebut di media sosial wibo dan menjelaskan apa yang sebenarnya telah terjadi . karena hal tersebut akhirnya pemerintah meminta maaf namun sudah terlambat."

Pada data tersebut terdapat tuturan ekspresif menyalahkan "...karena hal tersebut akhirnya pemerintah meminta maaf namun sudah terlambat.” Dituturkan oleh penyiar berita dengan maksud menyalahkan pemerintah atas sikap tidak baik yang ditujukan kepada dokter Li. Sikap meminta dokter Li untuk menandatangani surat berisi tuduhan telah membuat komentar palsu tentang virus corona padahal hal itu tidak benar membuat pemerintah sadar dan meminta maaf tetapi terlambat karena dokter Li telah meninggal dunia. Dan penutur menyalahkan dengan pernyataan namun sudah terlambat.

\section{SIMPULAN}

Berdasarkan penelitian diperoleh simpulan sebagai berikut. Analisis tindak tutur ekspresif dalam berita terdiri atas tindak tutur ekspresif yang meliputi tuturan ekspresif mengkritik, memuji, meminta maaf, dan menyalahkan. Pada tindak tutur ekspresif mengkiritik terdapat tiga data dan empat tuturan ekspresif. Pada tindak tutur ekspresif memuji terdapat tiga data dengan enam tuturan ekspresif. Pada tindak tutur ekspresif meminta maaf terdapat satu data dan satu tuturan ekspresif. Pada tindak tutur ekspresif menyalahkan terdapat satu data dan satu tuturan ekspresif. Sehingga secara keseluruhan jumlah tindak tutur ekspresif pada 
berita dokter yang pertama kali deteksi virus corona di Wuhan meninggal terdapat dua belas tindak tutur ekspresif.

Adapun saran yang dapat dianjurkan sebagai berikut: (a) Penelitian ini dibatasi hanya pada tindak tutur ekspresif saja, peneliti lain diharapkan ada yang mengkaji tindak tutur dari situasi tutur yang terjadi di tengah pandemi corona dengan tujuan penelitian yang berbeda. (b) Masyarakat luas diharapkan tidak menelan mentah-mentah infromasi yang belum diketahui kebenarannya. Pesatnya teknologi menyebabkan lebih cepat tersebarnya informasi. Adanya informasi yang dapat membuat kepanikan tidak lantas dapat dipercayai langsung namun tidak juga dijadikan alasan men-judge atau memaki seseorang karena informasi belum terbukti. Sehingga masih ada kemungkinan benar dan tidak benarnya informasi tersebut. Sumber data yang valid, keakuratan harus diteliti dan dicari kebenarannya sebelum mempercayai dan membagi ke media yang lain.

\section{DAFTAR PUSTAKA}

Rustono. (1999). Pokok-Pokok Pragmatik. Semarang: CV IKIP Semarang Press.

Sudaryanto. (1993). Metode dan Aneka Teknik Analisis Bahasa: Pengantar Penelitian. Yogyakarta: Duta Wancana.

Yule, George. (2006). Pragmatik. Yogyakarta: Pustaka Pelajar.

Ariyanti, L. D., \& Zulaeha, I. (2017). Tindak Tutur Ekspresif Humanis Dalam Interaksi Pembelajaran Di Sma Negeri 1 Batang: Analisis Wacana Kelas. Seloka: Jurnal Pendidikan Bahasa Dan Sastra Indonesia, 6(2), 111-122.

Septiani, Z., Juita, N., \& Emidar, E. (2016). Tindak Tutur Ekspresif dalam Talk Show Indonesia Lawak Klub. Pendidikan Bahasa Indonesia, 5(2), 568-573. FBS Universitas Negeri Padang.

Chamalah, E. (2016). Turahmat. 2016.“. Tindak Tutur Ekspresif pada Bak Truk sebagai Alternatif Materi Ajar Pragmatik.” Bahastra. Maret, 35, 27-40. Program Studi Pendidikan Bahasa dan Sastra Indonesia Universitas Islam Sultan Agung.

Nofrita, M. (2016). Tindak Tutur Ekspresif Mengkritik dan Memuji dalam Novel Padang Bulan dan Cinta Di Dalam Gelas Karya Andrea Hirata. Jurnal Pendidikan Rokania, 1(1), 51-60. Program Studi Pendidikan Bahasa dan Sastra Indonesia STKIP Rokania.

Prayitno, H. J. (2009). Perilaku Tindak Tutur Berbahasa Pemimpin dalam Wacana Rapat Dinas: Kajian Pragmatik Dengan Pendekatan Jender. Jurusan Pendidikan Bahasa Indonesia, FKIP, Unmuh Surakarta

Barus, E. E., \& Suprapto, A. D. H. (2018). Analisis Kualitas Website Tribunnews. com Menggunakan Metode Webqual dan Importance Performance Analysis. Jurnal Pengembangan Teknologi Informasi dan Ilmu Komputer e-ISSN, 2548, 964X. Fakultas Ilmu Komputer, Universitas Brawijaya 
Telaumbanua, D. (2020). Urgensi Pembentukan Aturan Terkait Pencegahan Covid19 di Indonesia. QALAMUNA: Jurnal Pendidikan, Sosial, dan Agama, 12(01), 59-70. Sekolah Tinggi Ilmu Hukum Nias Selatan

Irma, C. N. (2017). Tindak tutur dan fungsi tuturan ekspresif dalam acara rumah perubahan Rhenald kasali. SAP (Susunan Artikel Pendidikan), 1(3). Jurusan Pendidikan Bahasa dan Sastra Indonesia, Universitas Peradaban.

Parwanto, M. L. E. (2020). Virus Corona (2019-nCoV) penyebab COVID-19. Jurnal Biomedika dan Kesehatan, 3(1), 1-2. Fakultas Kedokteran Universitas Trisakti, Indonesia.

Yuliana, R., Rohmadi, M., \& Suhita, R. (2013). Daya Pragmatik Tindak Tutur Guru Dalam Pembelajaran Bahasa Indonesia Pada Siswa Sekolah Menengah Pertama. BASASTRA, 1(2), 280-293. Universitas Sebelas Maret, Surakarta.

Saefudin, S. (2013). Pendekatan Pragmatik dalam Mendukung Kemampuan Komunikasi Lisan. Buletin Al-Turas, 19(1), 1-12.

Garcia, M. J. B. (2018). Pragmatic Instruction May Not Be Necessary Among Heritage Learners of Spanish: A Study on Requests. Journal of Foreign Language Education and Technology, 3(1), 163-193.

Al-Hindawi, F. H., \& Ali, A. H. (2018). A Pragmatic Study of CNN and BBC News Headlines Covering the Syrian Conflict. Advances in Language and Literary Studies, 9(3), 43-51.

Xiao, F. (2015). Adult Second Language Learners' Pragmatic Development in the Study-Abroad Context: A Review. Frontiers: The Interdisciplinary Journal of Study Abroad, 25, 132-149.

Sari, F. D. P. (2012). Tindak tutur dan fungsi tuturan ekspresif dalam acara galau finite di Metro TV: suatu kajian pragmatik. Jurnal Skriptorium, 1(2), 114.

Purba, A. (2011). Tindak Tutur dan Peristiwa Tutur. Pena: Jurnal Pendidikan Bahasa dan Sastra, 1(1). Universitas Jambi.

Kirana, C., \& Sulistyo, E. T. (2018). Tuturan Ekspresif dalam Humor Politik Republik Sentilan Sentilun di Metro TV (Tinjauan Pragmatik). KEMBARA: Jurnal Keilmuan Bahasa, Sastra, dan Pengajarannya, 4(1). 